\title{
СОЕГОВ МУРАДГЕЛДИ
}

\section{КАК ПОЯВИЛИСЬ ЗАПИСИ НА АРМЯНСКОМ ЯЗЫКЕ НА ПЕРВЫХ ТУРКМЕНСКИХ ДЕНЕЖНЫХ КУПЮРАХ 1919 ГОДА}

Поводом для подготовки настоящей статьи послужил тот фракт, что необходимые сведения о денежных банкнотах, выпущенных Закаспийским Временным Правительством (ЗВП) в 1919 году в Ашхабаде с надписями не только на русском и туркменском языках, но и записями на армянском языке в армянском алфравите, по нашим наблюдениям не содержатся ни в опубликованных научных статьях по данной области знаний', ни в интернет-сайтах, предназначенных широкому кругу пользователей ${ }^{2}$. Но все это относится только к русскоязычным работам, ибо в нашей статье, выполненной на турецком языке и опубликованной в 2016 году, данная тема впервые в той или иной степени полноты получила свое освещение ${ }^{3}$.

1 Григорьянц В. "Переселение армян в Закаспийскую область (конец XIX начало XX вв.)", Lく9, 1977, № 2, стр. 64-73; Григорьянц В. "Участие армянпереселенцев в развитии торговли в Закаспийской области (конец XIX - начало XX вв.)", L<৭, 1978, № 6, стр. 53-66; Кадырбаев А. Ш. "Армянская диаспора и Дашнакцутюн в Туркестане. 1917-1921 годы". Восточный архив, 2013, № 2(28), стр. 32-39.

${ }^{2}$ Ерканян А., Армяне Туркмении [Электронный ресурс] URL: http: //sobesednikarmenii.ru/index.php/diaspora/85456-armyane-turkmenii (дата обращения: 24.10.2016); Многонациональный Туркменистан. Армяне [Электронный ресурс] URL: http://asgabat.net/stati/obschestvo/mnogonacionalnyi-turkmenistan-armjane .html (дата обращения: 23.10.2016); Петросян А. Армяно-туркменские отношения: взгляд из Еревана [Электронный ресурс] URL: http://infoabad.goodforum.net/t159-topic (дата обращения: 21.10.2016) и др.

${ }^{3}$ Söyegov M., Yüzünde Çaşdaş Türkmence Yazi Bulunan Illk Kaǧit Paralar, Çağdaş Türk Dili. Ekim Sayi: 344, Ankara (Türkiye), 2016, s. 504-507. 

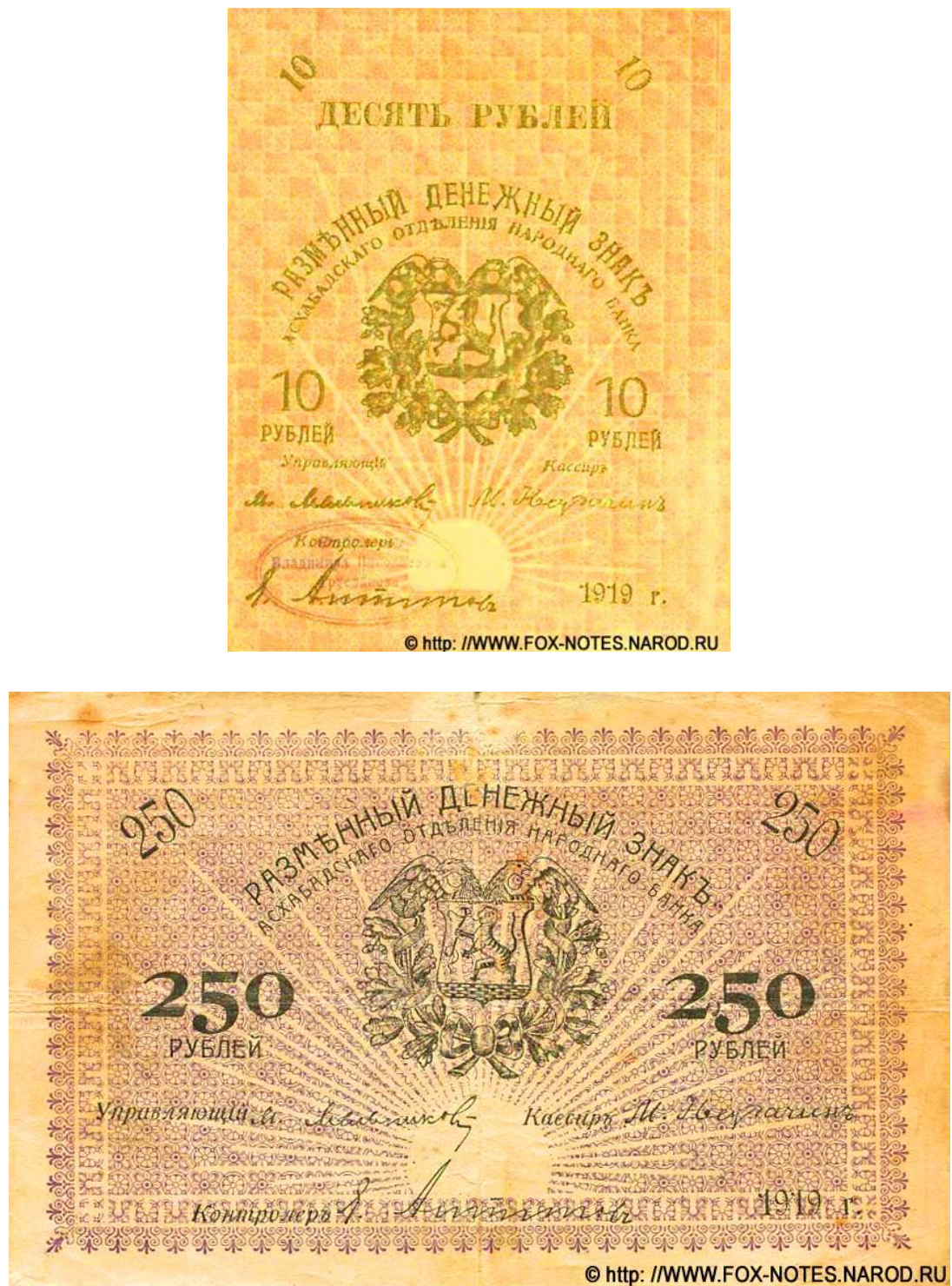

Рис. 1, 2. Аверс 10 и 250 рублевых банкнотов. 

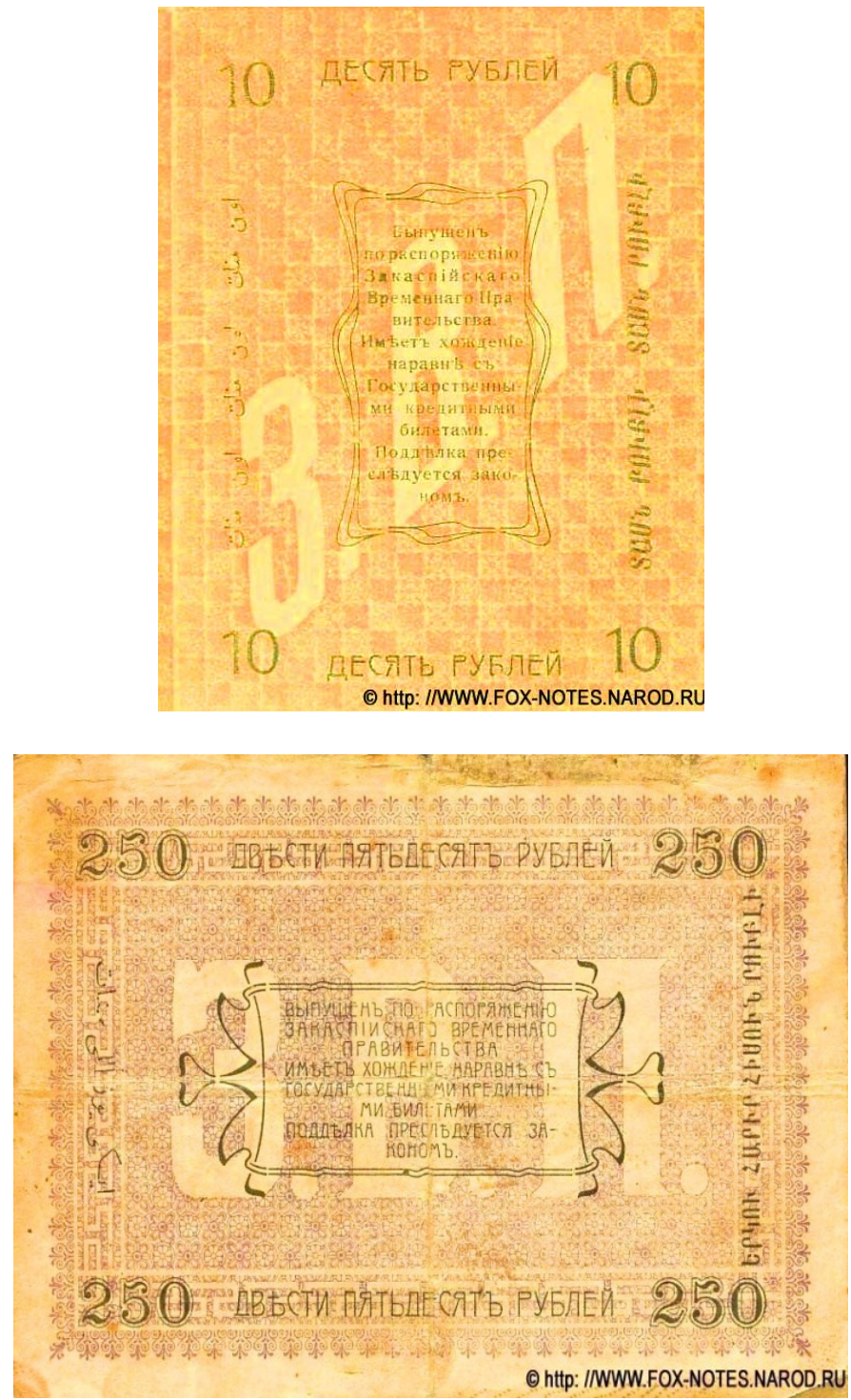

Рис. 3, 4. Реверс 10 и 250 рублевых банкнот с соответствующими надписями на армянском языке (на правой стороне). 
В этой связи в первую очередь следует отметить, что в отличие от русскоязычных записей в купюрах, которые напечатаны на кириллице, туркменские записи в них, как и следует, выполнены арабской вязью (на левой стороне реверса банкнотов). Можно утверждать, что записи на туркменском языке предназначались также казахам, азербайджанцам и представителям других тюркоязычных народов, населявших область и пользовавшихся в ту пору арабской графикой.

Для того, чтобы разобраться в причинах появления записей на армянском языке на банкнотах Временного Правительства Закаспийской (с 1921 года Туркменской) области, выпущенных в Ашхабаде в 1919 году, следует кратко рассмотреть некоторые вопросы истории Закаспийской области вообще, а также события, происходившие в области после фревраля и октября 1917 года. Начиная с 80-х годов XIX века, т.е. сразу же после присоединения значительной части туркменских земель к Российской империи под названием Закаспийская область, деловые представители армянских переселенцев приняли довольно заметное участие в развитии внутренней и внешней торговли в регионе. Армянские торговцы стали открывать в области различные торговые заведения, магазины, лавки, трактиры, гостиницы и т. п., причем интересы армянской торговой прослойки не ограничивались рамками крупных городов Закаспийского края, но проникали и во все мелкие городские поселения области и даже в сельские районы, непосредственно в аулы с местным населением. Крупные торговцы из армян принимали также видное участие в развитии внешней торговли с сопредельными странами: Ираном, Хивой, Бухарой и Афганистаном, ввозили товар в область с западного побережья Каспийского моря и из центральной России и выступали посредниками в русско-иранской торговле через Закаспийскую область. Армянское торговое население области часто выступало в роли предпринимателей-промышленников, многие крупные торговцы из армян были одновременно и владельцами промышленных предприятий в Закаспийской области ${ }^{4}$. Это - во-

4 Григорьянц В. "Переселение армян в Закаспийскую область (конец XIX начало XX вв.)", Lட૧, 1977, № 2, стр. 65; См. еще: Григорьянц В. "Участие 
первых. Во-вторых, в июне 1918 года большевистский Совнарком Туркестана объявил мобилизацию для использования сил против казаков с намерением отправить мобилизованных на Урал. Население Закаспийской области, где наряду местными туркменами проживало немало русских и армян, саботировало эту мобилизацию. Поэтому в Ашхабад был направлен из Ташкента отряд красногвардейцев во главе с чрезвычайным комиссаром Совнаркома Туркестанской Автономной Социалистической Республики (ТАСР) по Закаспийской области А.И. Фроловым, бойцы которого 12 июля 1918 года были полностью уничтожены восставшими в области.

В те же дни в Ашхабаде было создано Закаспийское Временное Правительство (Временный Исполнительный Комитет Закаспийской области), состоящее в основном из социалистов-революционеров и социал-демократов во главе с эсером Ф. А. Фунтиковым. Членами временного правительства состояли эсер Б.В. Курилов (товарищ, т.е. заместитель председателя), Л.А. Зимин, В. Духов, граф А.И. Доррер, генерал-лейтенант И.В. Савицкий; местное туркменское население в правительстве представляли участники Первой мировой войны: генерал-майор Ораз-сердар, офицеры бывшей Царской Армии Ходжагелди Хаджимурадов (Хаджи-Мурат), Сейитмурад Овезбаев и Хан Иомудский ${ }^{5}$ Была организована Закаспийская армия, которая под командованием главнокомандующего Закаспийским фронтом, генерал-майора Ораз-сердара вела не всегда успешные бои против Красной Армии ${ }^{6}$.

армян-переселенцев в развитии торговли в Закаспийской области (конец XIX начало XX вв.)", L८৭, 1978, № 6, стр. 53-66.

${ }^{5}$ См. Соегов М. "Уроженец Орла - один из первых доцентов БГУ, функционирующего с 1919 года", Ученые записки Орловского государственного университета. Серия: Гуманитарные и социальные науки. Орел, 2015, № 6 (69), стр. 74-78; Цветков В.Ж. "Между белым югом и Сибирью: специфика управления в Закаспийской области в 1918-1920 гг." [Электронный ресурс] URL: https://www.permgani. ru/publikatsii/konferentsii/grazhdanskaya-vojna-na-vostokerossii/v-zh-tsvetkov-mezhdu-belym-yugom-i-sibiryu-spetsifika-upravleniya-vzakaspijskoj-oblasti-v-1918-1920-gg.html (дата обращения: 12.11.2016).

${ }^{6}$ См. Соегов М. "Туркмены-командиры Царской и “Белой” Армий: генерал 
Закаспийское правительство обратилось 11 августа 1918 за помощью к главе британской военной миссии в Мешхеде (Персия) генералу У. Маллесону. Тот откликнулся на просьбу отправкой тогда и в последующем необходимой военной помощи антибольшевистскому правительству.

19 августа 1918 года Закаспийское Временное Правительство подписало с генералом Малессоном соглашение, по которому Закаспийская область фрактически переходила под власть английских интервентов. В январе 1919 года английский генерал разогнал Закаспийское Временное Правительство и установил военную диктатуру, создав марионеточный Комитет общественного спасения (в составе 5 чел.). Вскоре после ухода английских войск из области (апрель - июль 1919 г.) части Красной армии освободили Ашхабад (9 июля 1919 г.), а в феврале 1920 года - всю Закаспийскую область ${ }^{7}$.

В литературе отсутствуют сведения о непосредственном участии представителей армянского населения области в составе Закаспийского Временного Правительства, хотя говорится, что данное правительство объединило в себе все антибольшевистские силы области, в том числе представителей партии дашнаков ${ }^{8}$. В другом источнике содержатся данные о том, что к 25 сентября 1918 года "Белая" армия области состояла примерно из 1,2 тыс. индийцев и британцев плюс 1,5 тыс. русских, армян и туркмен 9 .

Подведя некоторые итоги вышеизложенному, можем констатировать, что во время правления Закаспийского Временного Прави-

Ораз-сердар, сын Дыкма-сердара", Научный Татарстан. Гуманитарные науки, 2015, № 3, стр. 43-49.

${ }^{7}$ См. Закаспийское Временное Правительство [Электронный ресурс] URL: http://www.hrono.ru/organ/ukaz_z/ru19170220.php (дата обращения: 12.11.2016); Интервенция 14 держав в Советскую Россию [Электронный ресурс] URL: http://volk59.narod.ru/inter14.htm (дата обращения: 12.11.2016).

${ }^{8}$ См. Закаспийское Временное Правительство [Электронный ресурс] URL: http://www.hrono.ru/organ/ukaz_z/ru19170220.php (дата обращения: 12.11.2016). ${ }^{9}$ См. Интервенция 14 держав в Советскую Россию [Электронный ресурс] URL: http://volk59.narod.ru/inter14.htm (дата обращения: 12.11.2016). 
тельства и затем Комитета общественного спасения торговля и финансового положения области регулировались через местные банки, как это было и раньше, при активном участии крупных армянских торговцев, которые одновременно были и владельцами промышленных предприятий. Таким образом, большой вес армянских предпринимателей в торгово-фринансовой системе Закаспийской области, в том числе в период правления Временного Правительства, обусловил появления записей на их родном армянском языке на денежных банкнотах, выпущенных в 1919 году.

Было выпущено всего 6 видов денежных знаков с достоинствами 5, 10, 25, 50, 100 и 250 рублей, каждый из которых имел оригинальное графическое офрормление и отличительную цветовую основу напечатанных бумаг (желто-серую, зеленую и др.). У всех купюр в аверсе изображен Герб Закаспийской области и несколько раз указывается в цифрах их достоинство. Наверху Герба написаны слова: “Разменный денежный знак Асхабадского отделения Народного банка”. Приводятся подписи управляющего, кассира и контролера, а также год выпуска банкноты - 1919 г.

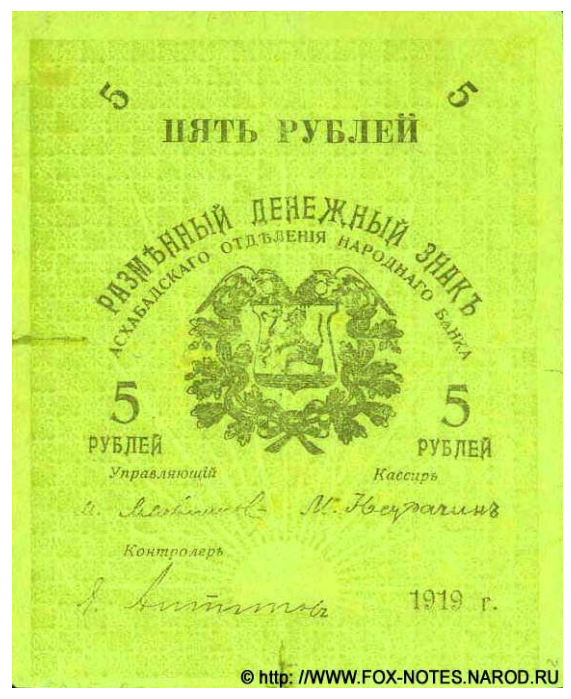




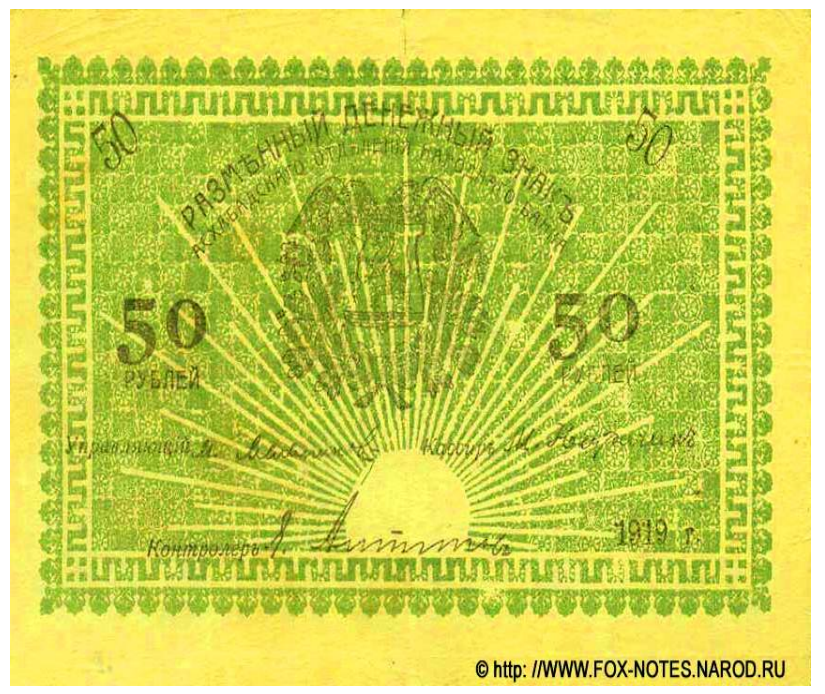

\section{Рис. 4, 5. Аверс 5 и 50 рублевых банкнотов.}

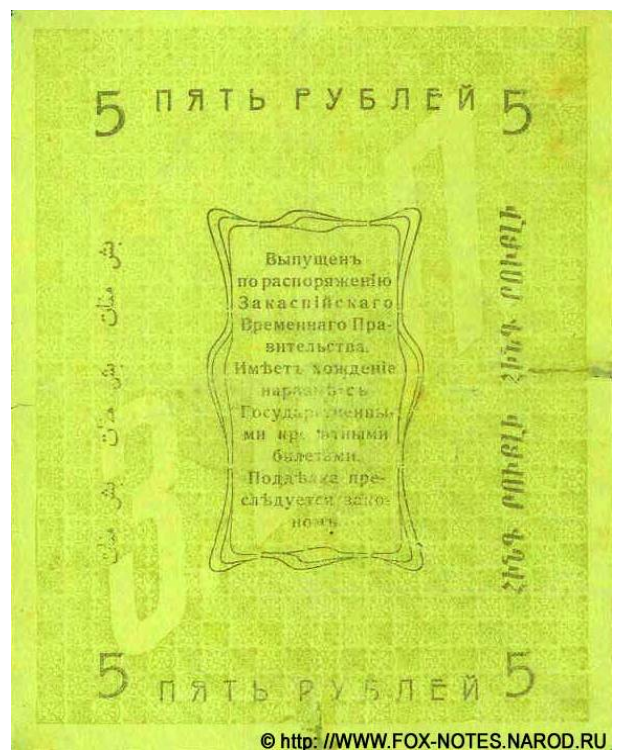




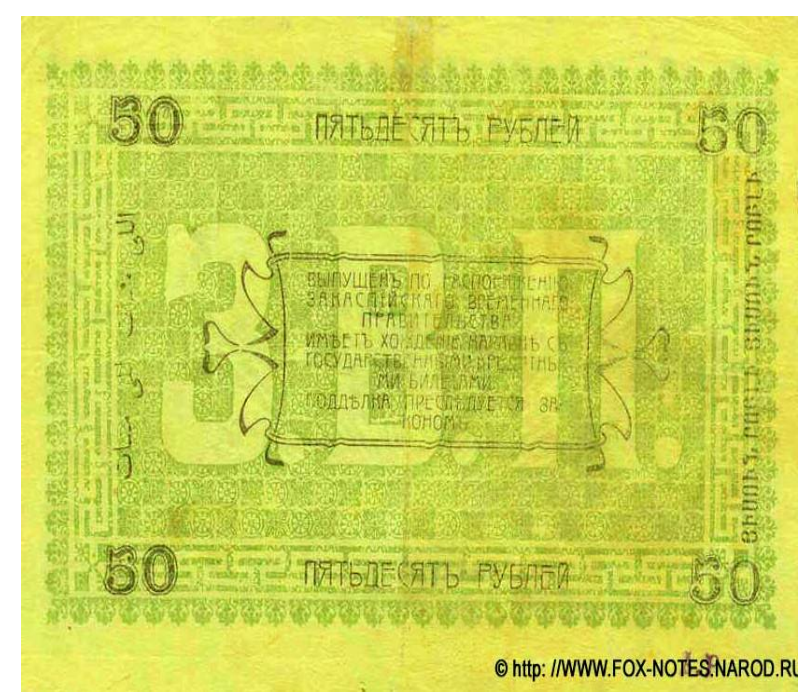

Рис. 6, 7. Реверс 5 и 50 рублевых банкнотов с соответствующими надписями на армянском языке (на правой стороне).

Реверс купюр в своем центре содержит сокращение в виде больших по объему букв 3.В.П., которое расшифровывается как Закаспийское Временное Правительство. Основу реверса составляют следующие предложения: "Выпущен по Распоряжению Закаспийского Временного Правительства. Имеет хождение наравне с государственными кредитными билетами. Подделка преследуется законом". Как в аверсе, достоинство банкнотов повторяется в реверсе приведением соответствующих цифр, а именно 5, 10, 25, 50, 100 и 250. Они повторяются словами на русском, туркменском и армянском языках (транскрипция туркменских слов в квадратных скобках с применением современного алфавита добавлены автором данной статьи):

Пять рублей -بش منات - ايكرمى منات- الون منات [ýigrimi b(ä)s m(a)nat] - puwühhưq nnıpLh. Пятьдесят рублей - اللى منات

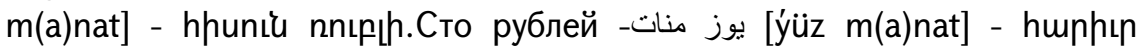
nnıpцh. Двести пятьдесят рублей - ايكى يوز مانت اiki ýüz elli m(a)nat] - tplnı 
huphın Jhunıı́ nnıpLh. Пятьсот рублей - بش يوز منات [b(ä)s ýüz m(a)nat] hpuq humjnın nnıpLh.

В конце отметим, что в том же 1919 году, когда Закаспийское Временное Правительство выпускало в Ашхабаде свои деньги с записями на купюрах на русском, туркменском и армянском языках, на севере современного Туркменистана глава туркменских повстанцев Джунейд-хан (Курбанмаммед-сердар), сменив прежнего хана на другого, более послушного хана на престоле Хивинского ханства (правопреемник древнего Хорезма), также выпускал свои деньги, но не на бумаге, а на шелке, с записями на туркменском языке, выполненными арабской вязью с использованием туркменского слова Но это тема уже для другой самостоятельной работы.

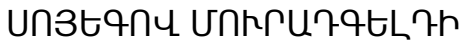

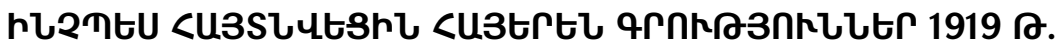

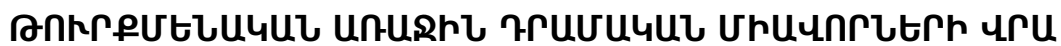

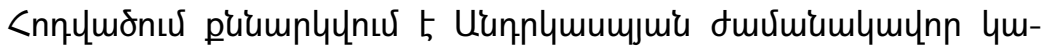

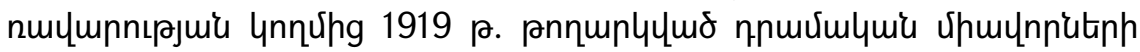
unu hujtritu qnnısniüutiph hungn:

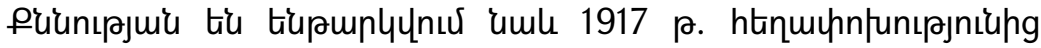

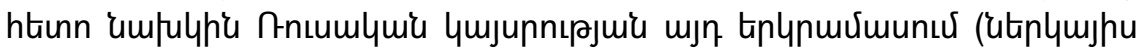

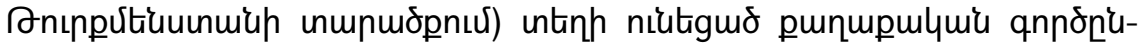
pughitinn: 